\title{
LANGUAGE ABILITY AND SPEECH COMPETENCE OF SCHOOLCHILDREN: ANALYSIS OF COGNITIVE MECHANISMS DEVELOPMENT ${ }^{1}$
}

\author{
Larisa O. Butakova \\ Omsk State University named after F.M. Dostoevsky, Omsk, Russian Federation
}

\begin{abstract}
The article shows the psycholinguistic description of native speakers' language ability and speech competence, based on the analysis of 6-7 grade pupils' essays written on free topics in the cognitive, communicative, semantic aspects. The author takes into account changes in the consciousness and behavior of native Russian speakers due to the early inclusion of children in communicative events on a global scale via the Internet, changes in the nature of leisure and leisure discourse.

Language ability and speech competence were interpreted in the cognitive aspect that allowed to describe the written language as an activity which manifests the presence / absence of the necessary operations, performance level of cognitive mechanisms, conscious / unconscious application of language / speech rules. This description is based on the understanding of language ability (following V. Pishchalnikova and E. Yakovchenko) as a set of operationally-effective mental mechanisms engaged in the verbalization of knowledge and skills; speech competence as the availability of operational structures and skills necessary for implementing a particular activity.

The author concludes that the volume of the texts corresponds to the normal development of language skills according to student's age; low variability of vocabulary and grammar is an indication of the average level of speech competence; egocentric orientation of text is the result of the orientation of modern academic discourse on the update of pupils' reflection and meta-reflection; presence of stereotypical cognitive, communicative, semantic strategies on the text design stage, formation of the current sense and their implementation; limited composition of concepts and their components are represented by a steady verbal sets, and it is also represented by the advertising speech strategy formed in the mind and actively used in the pupils' speech under the influence of popular communication formats.
\end{abstract}

Key words: speech activity, language ability, speech competence, cognitive competence, cognitive mechanisms.

УДК 81 '23

ББК 81.006

Дата поступления статьи: 06.10.2016

Дата принятия статьи: 10.11.2016

\section{ЯЗЫКОВАЯ СПОСОБНОСТЬ И РЕЧЕВАЯ КОМПЕТЕНЦИЯ ШКОЛЬНИКОВ: АНАЛИЗ СФОРМИРОВАННОСТИ КОГНИТИВНЫХ МЕХАНИЗМОВ ${ }^{1}$}

\author{
Лариса Олеговна Бутакова \\ Омский государственный университет им. Ф.М. Достоевского, г. Омск, Российская Федерация
}

\footnotetext{
Аннотация. В статье описаны языковая способность и речевая компетенция носителей русского языка школьного возраста на основе психолингвистического анализа сочинений на свободные темы в когнитивном, коммуникативном, семантическом аспектах с учетом изменений, происшедших в сознании и поведении носителей русского языка, обусловленных ранней включенностью детей в коммуникативные события глобального ․ масштаба с помощью сети Интернет, изменениями характера досуга и досугового дискурса.

Интерпретация полученных данных в когнитивном аспекте позволила представить письменную речь школьников как деятельность, в которой проявляется наличие / отсутствие необходимых операций, уровень сформированности когнитивных механизмов, осознанность / неосознанность нормы. Такое описание опирается на понимание языковой способности (вслед за В.А. Пищальниковой и Е. Яковченко) как совокупности операционально-действенных ментальных механизмов, осуществляющих вербализацию знаний и умений, речевой компетенции - как наличия необходимых для определенного вида деятельности операциональных структур и навыков их реализации.
} 
Установлено соответствие объема текстов сочинений учащихся возрастной норме развития языковой способности; выявлена невысокая вариативность лексических и грамматических средств на уровне высказывания и текста как показатель среднего уровня развития речевой компетенции; эгоцентрическая направленность текстов как следствие ориентации современного учебного дискурса на актуализацию рефлексии и метарефлексии учащихся; наличие у пишущих стереотипных когнитивных, коммуникативных, семантических стратегий на стадии замысла, формирования актуального смысла и его реализации. Обнаружены тенденции к репрезентации ограниченного состава концептов и их компонентов с помощью устойчивых вербальных наборов; к формированию в сознании и активному использованию в речи рекламных речевых стратегий под влиянием распространенных коммуникативных форматов.

Ключевые слова: речевая деятельность, языковая способность, речевая компетенция, когнитивная компетенция, когнитивные механизмы.

\section{1}

Рассуждения психологов, лингвистов и психолингвистов о происходящих трансформациях сознания носителей языка, изменении языковой ситуации, снижении речевой культуры, изменениях характера и типа коммуникации, когнитивных изменениях, обусловленных преобладанием видео-форм передачи информации над собственно вербальными, малым объемом чтения современных детей и подростков и пр., задают определенные направления в изучении речи учащихся школ. Одно из них - диагностика языковой способности и речевой компетенции, включающая и оценку уровня сформированности когнитивных механизмов, а также характера когнитивных изменений.

Ответить на вопросы о том, происходят ли когнитивные изменения, каково состояние языковой способности и речевой компетенции школьников среднего возраста, «что там за словом» в их ментальном лексиконе, можно только в результате широкомасштабных исследований. Один из распространенных путей их проведения - описание состава и структуры ментального лексикона как динамической системы, ядра языкового сознания, значения как достояния индивида в позднем онтогенезе и пр. В этом проблемном поле российской психолингвистикой накоплен значительный материал [1-4; 7-13; 15; 18; 19; и др.]. Основа указанных описаний по преимуществу ассоциативный эксперимент, в том числе лонгитюдный, с обработкой результатов «по горизонтали» и «по вертикали».

Другой путь - анализ письменной и / или устной речи. В данной статье внимание сосредоточено на исследовании письменной речи: анализ письменных работ школьников является частью проекта, посвященного описанию разных сторон коммуникации с участием детей и для детей в одном регионе (Омск, Омская область).

\section{2}

Цель статьи - определить уровень языковой способности и речевой компетенции, установить специфику письменной речи учащихся среднего возраста с позиций теории речевой деятельности на основе сопоставительного анализа сочинений на заданные темы. При этом принимались во внимание изменения, происходящие в русской письменной коммуникации в целом, в том числе активное вторжение интернет-дискурсов в жизнь молодых носителей языка [5; 6], и учитывались ранняя включенность детей в коммуникативные события глобального масштаба с помощью сети Интернет, изменения характера досуга и досугового дискурса.

Языковая способность в парадигме теории речевой деятельности интерпретируется как совокупность операционально-действенных ментальных механизмов, осуществляющих вербализацию знаний и умений [16, с. 5], языковая (речевая) компетенция - как наличие необходимых для определенного вида деятельности операциональных структур и навыков их реализации $[17$, с. 15$]$, когнитивная компетенциия - как набор универсальных оптимизирующих когнитивных стратегий, база для развития языковой и коммуникативной компетенции индивида [20, с. 10].

Развитая языковая (речевая) компетенция проявляется в наличии необходимых операций в речевой деятельности носителя языка, сформированности когнитивных механиз- 
мов, интериоризации нормированных областей, осознанности нормы [1, с. 15].

Состояние недостаточно развитой языковой способности и речевой компетенции «выражается в невозможности (или затрудненности) вербализации ментального содержания адекватными языковыми средствами, выбранными в зависимости от целей коммуникации. Нарушение когнитивных механизмов означивания влечет за собой плохую работу языковой и коммуникативной компетенций. Сбои действия языковой и коммуникативной компетенции являются следствием плохого функционирования когнитивной компетенции / языковой способности» [1, с. 17].

Для определения уровня развития языковой способности и речевой компетенции школьников, установления комфортных форматов общения, речевых предпочтений учащимся 4-8-х классов средних школ г. Омска и Омской области были предложены следующие темы сочинений (жанр письменного текста выбирался пишущими самостоятельно): «Однажды я услышал / прочитал, что...», «Если бы не было компьютеров и планшетов, то...», «Если бы не было книжек, то...», «Мой город» («Где я люблю бывать в Омске? Почему?»), «Важный разговор в моей жизни», «На кого я хочу быть похожим», «Прочитать или посмотреть?», «Мой любимый мультфильм / фильм?», «Нужен ли мне телевизор?», «Друг в “Одноклассниках" - это друг?».

Сочинения были написаны в сентябре октябре 2015 г. и в сентябре - октябре 2016 г. (всего более 800 работ в жанрах эссе, минисочинения, сочинения, риторического выступления, рекламы); преобладающими оказались работы на темы: «Если бы не было компьютеров и планшетов, то...» (далее - тема I), «Мой город» («Где я люблю бывать в Омске? Почему?») (далее - тема II), «На кого я хочу быть похожим» (далее - тема III).
В статье подробно рассмотрим сочинения на указанные темы, написанные учащимися 67-х классов школ и гимназий г. Омска.

$$
3
$$

Письменные работы учащихся оценивались в коммуникативном (включенность любого речевого события в ситуативный набор, создающий дискурсивные объекты, подчиненность определенным стратегиям и тактикам, тип речевого взаимодействия), когнитивном (наличие актуализированных когнитивных структур, образованных на основе компонентов концептов, их сложность / простота, связи друг с другом), семантическом (отбор слов, распределение предметных признаков, выделение предикатов, связь предложений) аспектах (о критериях анализа см.: [1, с. 88-92]).

Средний объем сочинений семиклассников на тему I таков: 110,37 слова, 8,2 предложения, среднее количество слов в предложении - 13,45; самое большое сочинение насчитывает 218 слов, 19 предложений, среднее количество слов в предложении - 11,47; самое маленькое - 39 слов, 3 предложения, среднее количество слов в предложении - 13 (табл. 1). Такое соотношение среднего количества слов в предложениях самого большого и самого маленького сочинений указывает на наличие зафиксированной Н.И. Жинкиным тенденции к сглаживанию в данном возрасте различий между минимальным и максимальным количеством слов и невысокой интенсивности «планирующего синтеза» в процессе написания текста [14, с. 200-201].

Средний объем сочинений учащихся 6-х классов о родном городе (тема II) 146,6 слова, 16 предложений, 9,1 слова в предложении; самое большое сочинение - 197 слов, 20 предложений, 9,85 слова в предложении; самое маленькое сочинение - 20 слов, 3 предложения, 6,6 слова в предложении (см. табл. 2).

Таблиия 1

Объем сочинений учащихся 7-х классов на тему «Если бы не было компьютеров и планшетов, то...», 2015 г.

\begin{tabular}{|c|c|c|}
\hline \multicolumn{3}{|c|}{ Объем сочинения } \\
\hline Средний & Максимальный & Минимальный \\
\hline 8,2 предложения & 19 предложений & 3 предложения \\
110,37 слова & 218 слов & 39 слов \\
\hline \multicolumn{2}{|c|}{ Среднее количество слов в предложении } \\
\hline 13,45 слова & 11,47 слова & 13 слов \\
\hline
\end{tabular}


Л.О. Бутакова. Языковая способность и речевая компетенция школьников

Объем сочинений учащихся 6-х классов на тему «Мой город»

Таблийа 2 («Где я люблю бывать в Омске? Почему?»), 2015 г.

\begin{tabular}{|c|c|c|}
\hline \multicolumn{3}{|c|}{ Объем сочинения } \\
\hline Средний & Максимальный & Минимальный \\
\hline 16 предложений & 20 предложений & 3 предложения \\
146,6 слова & 197 слов & 20 слов \\
\hline \multicolumn{3}{|c|}{ Среднее количество слов в предложении } \\
\hline 9,1 слова & 9,85 слова & 6,6 слова \\
\hline
\end{tabular}

Средний объем сочинений учащихся 7-х классов на эту же тему - 106,1 слова, 10,15 предложения, 10,45 слова в предложении; самое большое сочинение насчитывает 274 слова, 22 предложения, 12,45 слова в предложении; самые маленькие сочинения 16 слов, 4 предложения, 4 слова в предложении и 32 слова, 3 предложения, 10,6 слова в предложении (табл. 3).

Эти показатели примерно совпадают в двух основных группах сочинений, выделенных нами на основе базовой коммуникативной стратегии: о любимых местах г. Омска и о самом городе (39 работ, средний объем 109,1 слова, 9,1 предложения, 11,98 слова в предложении); о том, что авторы хотели бы изменить в г. Омске (12 работ, средний объем - 103,1 слова, 11,2 предложения, 9,2 слова в предложении). При этом средний объем работ шестиклассников оказался выше на 40 слов $(146,6 / 106,1)$ и на 5,85 в предложениях $(16 / 10,15)$, что можно связать с субъективным фактором - психологическими осо- бенностями авторов, их мотивацией к речевой деятельности и пр., однако у семиклассников среднее количество слов в предложении на 1,35 больше $(10,45$ / 9,1).

Такие показатели свидетельствуют о том, что письменные тексты учащихся 6-7-х классов на темы I и II формально соответствуют возрастной норме развития языковой способности и речевой компетенции.

Сочинения семиклассников на тему III, соответствующие возрастной норме по объему, оказались «бедными» в смысловом отношении, несложными в структурном и коммуникативном. Самое большое сочинение насчитывает 153 слова, 13 предложений, 11,76 слова в предложении; самое маленькое сочинение состояло всего из одного предложения и 8 слов (табл. 4).

Такие показатели можно объяснить как общей коммуникативной стратегией текстов, так и стремлением половины пишущих дать отрицательный ответ на поставленный в формулировке темы вопрос.

Таблица 3

Объем сочинений учащихся 7-х классов на тему «Мой город» («Где я люблю бывать в Омске? Почему?»), 2015 г.

\begin{tabular}{|c|c|c|}
\hline \multicolumn{3}{|c|}{ Объем сочинения } \\
\hline Средний & Максимальный & Минимальный \\
\hline 10,15 предложения & 22 предложения & $4 / 3$ предложения \\
106,1 слова & 274 слова & $16 / 32$ слова \\
\hline \multicolumn{3}{|c|}{ Среднее количество слов в предложении } \\
\hline 10,45 слова & 12,45 слова & $4 / 10,6$ слова \\
\hline
\end{tabular}

Объем сочинений учащихся 7-х классов на тему «На кого я хочу быть похожим», 2016 г.

\begin{tabular}{|c|c|c|}
\hline \multicolumn{3}{|c|}{ Объем сочинения } \\
\hline Средний & Максимальный & Минимальный \\
\hline 12,5 предложения & 13 предложений & 1 предложение \\
166,2 слова & 153 слов & 8 слов \\
\hline \multicolumn{3}{|c|}{ Среднее количество слов в предложении } \\
\hline 9,28 слова & 11,76 слова & 8 слов \\
\hline
\end{tabular}


4

Коммуникативная организация текстов сочинений отражает коммуникативные форматы современной письменной и отчасти устной речи.

4.1. В сочинениях на тему I доминирует эксплицитная Я-коммуникация, передающая рефлексию говорящего над самим собой и своей жизнью (табл. 5). Это можно объяснить возрастанием индивидуального начала в российском обществе вообще и речевой практике школьников в частности. Кроме того, учебный дискурс ориентирует школьников на передачу собственного мнения (подробное описание сочинений на эту тему см.: [3]).

4.2. В сочинениях на тему II реализуются две смысловые стратегии: описание любимых мест города и рассуждения о том, что авторы хотели бы изменить в родном городе.

Коммуникативная организация сочинений о любимых местах города и о самом городе обнаруживает 4 типа коммуникативных сценариев, связанных с реалистической модальностью передачи информации (табл. 6):
- бессубъектное описательное повествование об известных и красивых объектах города, переходящее в середине текста в Я- / Мы-коммуникацию, реализовано с помощью речевых стратегий информирования о статусе, величине, эстетической значимости, истории города и его мест и личной причастности к ним (Омск - один из самых красивейших городов Западной Сибири; Музыкальный театр - один из самых интересных развлекательных мест в Омске; Улица Чокана Валиханова находится в историческом иентре города Омска);

- Я- / Мы-коммуникация, передающая рефлексию говорящего по поводу любимых мест города, реализована с помощью речевых стратегий антропоцентрической генерализации, пространственного выделения и личностного приобщения (У каждого человека есть то место, которое он любит больше всего, где он родился и вырос. Это место называется Родиной. Моя родина - город Омск, прекрасный и солнечный; У каждого из нас есть любимые места в городе. Мое любимо место - это Соборная площадь);

Таблииа 5

Коммуникативная организация текстов сочинений учащихся 7-х классов на тему «Если бы не было компьютеров и планшетов, то...», 2015 г.

\begin{tabular}{|c|c|c|}
\hline \multicolumn{3}{|c|}{ Коммуникативные сценарии } \\
\hline Эксплицитная Я-модель & $\begin{array}{l}\text { Косвенная коммуникация, } \\
\text { включающая субъекта в со- } \\
\text { циумную группу }\end{array}$ & $\begin{array}{l}\text { Отсутствие выраженного } \\
\text { коммуникативного начала }\end{array}$ \\
\hline $26 \%$ & $41 \%$ & $33 \%$ \\
\hline \multicolumn{3}{|c|}{ Речевые стратегии } \\
\hline $\begin{array}{l}\text { Рефлексия говорящего над } \\
\text { самим собой и своей жизнью }\end{array}$ & $\begin{array}{l}\text { Рассуждения о компьютерном } \\
\text { феномене, тех ническом про- } \\
\text { грессе, отношениях между } \\
\text { членами семьи, друзьями }\end{array}$ & $\begin{array}{l}\text { Общая характеристика гло- } \\
\text { бального масштаба техниче- } \\
\text { ского прогресса / деградации, } \\
\text { времени и мира }\end{array}$ \\
\hline
\end{tabular}

Таблица 6

Коммуникативная организация текстов сочинений учащихся 7-х классов на тему «Мой город» («Где я люблю бывать в Омске? Почему?»), 2015 г.

\begin{tabular}{|c|c|c|c|}
\hline \multicolumn{4}{|c|}{ Коммуникативные сценарии } \\
\hline $\begin{array}{l}\text { Бессубъектное описатель- } \\
\text { ное повествование, пере- } \\
\text { ход в середине текста к Я- } \\
\text { / Мы-коммуникации }\end{array}$ & $\begin{array}{l}\text { Я- / Мы-коммуникация } \\
\text { (рефлексия говорящего по } \\
\text { поводу любимых мест го- } \\
\text { рода) }\end{array}$ & $\begin{array}{l}\text { Я-коммуникация (стрем- } \\
\text { ление рассказать о люби- } \\
\text { мых местах) }\end{array}$ & $\begin{array}{l}\text { Я- / Мы- / Вы- } \\
\text { коммуникация (рекламная } \\
\text { стратегия приглашения на } \\
\text { экскурсию, совет) }\end{array}$ \\
\hline $60 \%$ & $17,5 \%$ & $7,5 \%$ & $15 \%$ \\
\hline \multicolumn{4}{|c|}{ Речевые стратегии } \\
\hline $\begin{array}{l}\text { Информирование о статусе, } \\
\text { величине, эстетической } \\
\text { значимости, истории горо- } \\
\text { да, личной причастности }\end{array}$ & $\begin{array}{l}\text { Антропоцентрическая ге- } \\
\text { нерализация, пространст- } \\
\text { венное выделение и лич- } \\
\text { ностное приобщение }\end{array}$ & «Заявление о намерениях» & $\begin{array}{l}\text { Приглашение, предложе- } \\
\text { ние, обнародование нуж- } \\
\text { ной для адресата инфор- } \\
\text { мации о товарах и услугах }\end{array}$ \\
\hline
\end{tabular}


- Я-коммуникация, передающая стремление рассказать о любимых местах, реализована с помощью речевой стратегии «заявление о намерениях» (Я хочу рассказать вам о своем родном городе Омске, о том, какие красивые места в нем есть; Я хочу рассказать про иирк);

- Я- / Мы- / Вы-коммуникация, реализующая рекламную стратегию приглашения на экскурсию с элементами совета, воплощена с помощью речевых стратегий приглашения, предложения, обнародования нужной для адресата информации о товарах и услугах (Уважаемые омичи и гости нашего города. Приглашаем вас в досуго-развлекательный иентр «Галактика». Мы рады предложить вам провести романтический вечер в ресторане Бочка, стейк-хаус Коровка и перекусить в Бургер-Кинге; Знаете ли вы где можно провести иелый день с пользой? Знаете, где можно найти большое разнообразие одежды и обуви? Ответ один «Mегa»).

В сочинениях о том, что авторы хотели бы изменить в г. Омске, зафиксирован только один тип коммуникативной организации эксплицитная безадресная Я-коммуникация. Он реализован с помощью речевых стратегий сообщения о собственном ментальном, аффективном, перцептивном состоянии и «заявления о намерениях», связанных с гипотетической модальностью передачи информации (Мне очень нравится наш город, он очень красивый и интересный. Но когда я хожу по грязным улицам города, наблюдая за унылыми и хмурыми прохожими, мне становится очень грустно; Я люблю свой город и поэтому хочу сделать его лучше; Я считаю, что в Омске нужно построить метро).

4.3. В сочинениях на тему III преобладающей является эксплицитная Я-коммуникация, спровоцированная формулировкой: школьники прямо отвечали на вопрос «На кого я хочу быть похожим», повторяя или не повторяя его (табл. 7). Не случайно в начальных частях текстов была актуализирована сфера желаний (предикат хочу с отрицательной частицей или без нее). Незначительное количество работ начиналось с общих рассуждений о наличии в мире выдающихся людей. Как правило, в таких текстах далее следовали описания достоинств обычных людей и делался вывод о том, что важнее быть достойным, чем знаменитым, человеком.

В этих сочинениях ярко проявляется тенденция к индивидуализации: 29,4 \% сочинений от общего числа работ на указанную тему содержали категоричные утверждения о нежелании следовать идеалу, вопросы-недоумения, «декларации независимости» (Я ни на кого не хочу быть похожим. Я хочу быть собой; Я не хочу быть похожим ни на кого, кроме самой себя; Зачем быть похожим на другого человека; Я хочу сама создавать свою жизнь, а не по примеру кого-то).

\section{5}

Когнитивная организация текстов сочинений связана с реализацией набора концептов, актуализированных в речевых произведениях школьников.

5.1. Анализ сочинений на тему I обобщенно представлен в таблице 8 (подробную характеристику таких сочинений см. в: [4]).

Таблица 7

Коммуникативная организация текстов сочинений учащихся 7-х классов на тему «На кого я хочу быть похожим», 2016 г.

\begin{tabular}{|c|c|}
\hline \multicolumn{2}{|c|}{ Коммуникативные сценарии } \\
\hline $\begin{array}{l}\text { Бессубъектное рассуждение, переход } \\
\text { к Я-коммуникации }\end{array}$ & $\begin{array}{l}\text { Я-коммуникация (рефлексия говорящего по } \\
\text { поводу своих желаний, стремлений ) }\end{array}$ \\
\hline $11,7 \%$ & $88,3 \%$ \\
\hline \multicolumn{2}{|c|}{ Речевые стратегии } \\
\hline $\begin{array}{l}\text { Генерализация: рассуждения о наличии в } \\
\text { мире людей, которые могут быть эталонами } \\
\text { в той или иной сфере / личностное выделе- } \\
\text { ние: стремление каждого избрать пример для } \\
\text { подражания }\end{array}$ & $\begin{array}{l}\text { «Заявление о намерениях»: антропоцентри- } \\
\text { ческое выделение, личностное приобщение, } \\
\text { доказывание неслучайности выбора / утвер- } \\
\text { ждение нежелания быть похожим на кого- } \\
\text { либо, стремление быть самим собой }\end{array}$ \\
\hline
\end{tabular}


Сочинения на тему I сложны в семантическом, смысловом и структурном отношении. В ходе последовательного развертывания замысла говорящим вводились компоненты одних концептов через средства ак- туализации когнитивных структур других, сохранялся основной предмет речи и изменялись его предикатные характеристики, тема-рематические отношения выстраивались параллельно; одновременно актуализи-

Таблииа 8

\section{Способы когнитивного и семантического развертывания текстов сочинений} учащихся 7-х классов на тему «Если бы не было компьютеров и планшетов, то...», 2015 г.

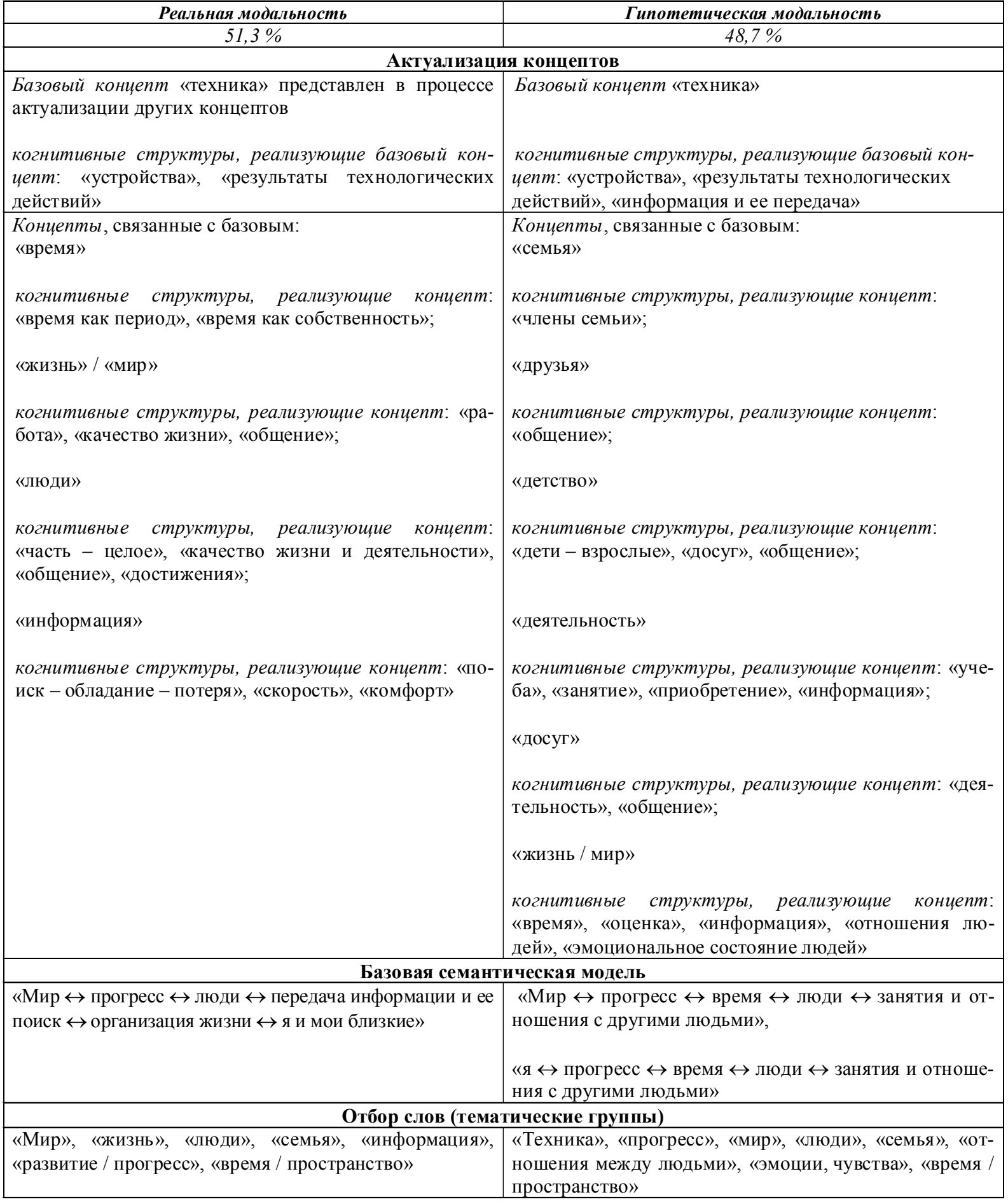


ровались разные компоненты одних и тех же концептов, при этом концепт «техника» был репрезентирован в ходе актуализации других концептов.

5.2. В сочинениях учащихся 6-7-х классов на тему II актуализировались пересекаю- щиеся концепты, составляющие концептуальное пространство «город Омск»: «город», «история», «события», «родина», «торговля», «развлечения», «люди», «любовь» (табл. 9).

Концепт «город» связан с концептом «родина», вариативно актуализировался в ходе

\section{Способы когнитивного и семантического развертывания текстов сочинений} учащихся 6-7-х классов на тему «Мой город» («Где я люблю бывать в Омске? Почему?»), 2015 г.

\begin{tabular}{|c|c|c|c|}
\hline \multicolumn{4}{|c|}{$\begin{array}{c}\text { Реальная описательная модальность } \\
85 \%\end{array}$} \\
\hline \multicolumn{4}{|c|}{ Актуализация концептов } \\
\hline \multicolumn{4}{|c|}{ Концепт «город» } \\
\hline \multicolumn{4}{|c|}{ Базовая семантическая модель } \\
\hline \multicolumn{4}{|c|}{ («Человек ↔ любимое место ↔ родина ↔ мой город ↔ определенный локус ↔ люди») } \\
\hline \multicolumn{2}{|c|}{$\begin{array}{l}\text { Когнитивные структуры, реализующче локативный } \\
\text { колпонент кониепта: } \\
\text { «город», «река», «набережная», «крепость» }\end{array}$} & \multicolumn{2}{|c|}{$\begin{array}{l}\text { Когнитивные структуры, реализующие субъектный } \\
\text { компонент концепта: } \\
\text { «друзья», «я», «члены моей семьи» }\end{array}$} \\
\hline \multicolumn{4}{|c|}{ Отбор слов (тематические группы) } \\
\hline \multicolumn{2}{|c|}{$\begin{array}{l}\text { «Исторические места, объекты», «объекты культуры», } \\
\text { «Экологические объекты» }\end{array}$} & \multicolumn{2}{|c|}{ «Семья», «мои друзья», «жители города» } \\
\hline \multicolumn{4}{|c|}{ Концепт «история» } \\
\hline \multicolumn{4}{|c|}{ Базовая семантическая модель } \\
\hline \multicolumn{4}{|c|}{ «Указ Петра I ↔ основание города ↔ строительство крепости ↔ история Омского драматического театра» } \\
\hline \multicolumn{2}{|c|}{$\begin{array}{l}\text { Когнитивные структуры, реализующие предметный } \\
\text { компонент концеепта: «город», «крепость», «драмати- } \\
\text { ческий театр», «памятники» }\end{array}$} & \multicolumn{2}{|c|}{$\begin{array}{l}\text { Когнитивные структуры, реализующие пространст- } \\
\text { венно-временной компонент концепта: «отдаленное } \\
\text { время», «настоящее время», «история», «историческая } \\
\text { часть города» }\end{array}$} \\
\hline \multicolumn{4}{|c|}{ Отбор слов (тематические группы) } \\
\hline \multicolumn{4}{|c|}{ «Причины и история появления города», «историческая часть города», «объекты культуры» } \\
\hline \multicolumn{4}{|c|}{ Концепт «события» } \\
\hline \multicolumn{4}{|c|}{ Базовые семантические модели } \\
\hline \multicolumn{2}{|c|}{$\begin{array}{l}\text { «Спортивные события } \leftrightarrow \text { город } \leftrightarrow \text { международный } \\
\text { статус } \leftrightarrow \text { мое участие» }\end{array}$} & \multicolumn{2}{|c|}{$\begin{array}{l}\text { «Хоккейные игры } \leftrightarrow \text { ведущий клуб города } \leftrightarrow \text { бо- } \\
\text { лельщики ↔ мои эмоции и переживания» }\end{array}$} \\
\hline \multicolumn{2}{|c|}{$\begin{array}{l}\text { Когнитивные структуры, реализующуе предметный, } \\
\text { оценочный, ассоциативный компоненты концепта: } \\
\text { «Сибирский марафон», «спортсмены», «хорошо», «ин- } \\
\text { терес», «бег», «прохождение дистанции» }\end{array}$} & \multicolumn{2}{|c|}{ 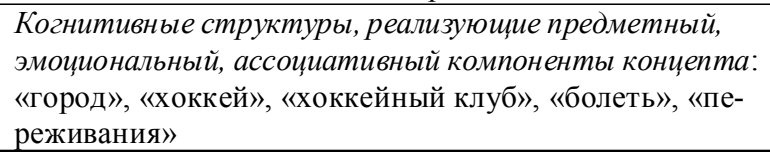 } \\
\hline \multicolumn{4}{|c|}{ Отбор слов (тематические группы) } \\
\hline \multicolumn{2}{|c|}{$\begin{array}{l}\text { «Международный Сибирский марафон», «памятник } \\
\text { марафону», «мое участие»» }\end{array}$} & \multicolumn{2}{|c|}{ «Авангард», «болельщики», «мои переживания» } \\
\hline \multicolumn{4}{|c|}{ Концепть «торговля», «развлечения» } \\
\hline \multicolumn{4}{|c|}{ Базовая семантическая модель } \\
\hline \multicolumn{4}{|c|}{$\begin{array}{l}\text { «Конкретный локус } \leftrightarrow \text { величина } \leftrightarrow \text { выбор } \leftrightarrow \text { одежда / обувь } \leftrightarrow \text { развлечения } \leftrightarrow \text { дети / взрослые } \leftrightarrow \text { польза } \leftrightarrow \\
\text { комфорт» }\end{array}$} \\
\hline $\begin{array}{l}\text { Когнитивные структуры, реали- } \\
\text { зующчие локативный компонент } \\
\text { концепта: «ведущие торговые мес- } \\
\text { та», «город» }\end{array}$ & \multicolumn{2}{|c|}{$\begin{array}{l}\text { Когнитивные структурь, реали- } \\
\text { зующие субъектный компонент } \\
\text { концеетта: «семья», «друзья», } \\
\text { «детство», «деятельность людей» }\end{array}$} & $\begin{array}{l}\text { Когнитивные структуры, реализую- } \\
\text { щуие эмоционально-оценочный компо- } \\
\text { нент концепта: «радость», «хороший } \\
\text { отдых», «приятные покупки» }\end{array}$ \\
\hline \multicolumn{4}{|c|}{ Отбор слов (тематические группы) } \\
\hline $\begin{array}{l}\text { «Ведущие торговые места города», } \\
\text { «конкретные номинации молов» }\end{array}$ & $\begin{array}{l}\text { «Члены семьи», } \\
\text { «друзья», «поку } \\
\text { «отдых», } \\
\text { «дети / взрослые } \\
\text { обретение товаро }\end{array}$ & $\begin{array}{l}\text { Іки», «общение», } \\
\text { », «досуг», «при- } \\
\text { в и услуг» }\end{array}$ & $\begin{array}{l}\text { «Позитивные эмоции», «отдых», } \\
\text { «Покупки» }\end{array}$ \\
\hline
\end{tabular}


Окончание таблицы 9

\begin{tabular}{|c|c|c|}
\hline \multicolumn{3}{|c|}{$\begin{array}{c}\text { Рекламная стратегия } \\
15 \%\end{array}$} \\
\hline \multicolumn{3}{|c|}{ Актуализация концептов } \\
\hline \multicolumn{3}{|c|}{ Концепты «торговля», «развлечения» } \\
\hline $\begin{array}{l}\text { Когнитивные структуры, реали- } \\
\text { зующие локативный компонент } \\
\text { концептов: } \\
\text { «ведущие торговые места города», } \\
\text { «конкретные номинации молов», } \\
\text { «природа», «культура» }\end{array}$ & $\begin{array}{l}\text { Когнитивные структуры, реали- } \\
\text { зующчие субъектный компонент } \\
\text { концепта: } \\
\text { «семья», «друзья», «детство», } \\
\text { «торговля», «отдых» }\end{array}$ & $\begin{array}{l}\text { Когнитивные структуры, реали- } \\
\text { зуюшие эмоционально-оценочный } \\
\text { компонент концепта: } \\
\text { «утилитарная польза», «позитив- } \\
\text { ные эмоции», «интерес», «радость» }\end{array}$ \\
\hline \multicolumn{3}{|c|}{ Базовая семантическая модель } \\
\hline \multicolumn{3}{|c|}{$\begin{array}{l}\text { «Уникальное торговое предложение } \leftrightarrow \text { приглашение посетить крупные торговые объекты города } \leftrightarrow \text { уверен- } \\
\text { ность в получении позитивных эмоций» }\end{array}$} \\
\hline \multicolumn{3}{|c|}{ Отбор слов (тематические группы) } \\
\hline $\begin{array}{l}\text { «Популярные торговые места го- } \\
\text { рода», «конкретные номинации } \\
\text { молов», «интересные природные и } \\
\text { культурные места города» }\end{array}$ & $\begin{array}{l}\text { «Члены семьи», } \\
\text { «друзья», «покупки», «общение», } \\
\text { «отдых», } \\
\text { «дети / взрослые», «досуг», «при- } \\
\text { обретение товаров и услуг» }\end{array}$ & $\begin{array}{l}\text { «Покупки», общение», «отдых», } \\
\text { «скорость, экономия», «комфорт», } \\
\text { «обилие товаров и услуг», } \\
\text { «интересно взрослым и детям», } \\
\text { «отсутствие сожаления» }\end{array}$ \\
\hline
\end{tabular}

семантического развертывания базовой семантической модели с локативными и субъектными компонентами: «человек - любимое место - родина - мой город - определенный локус - люди». В реализациях модели локативный компонент представлен обширно с помощью традиционного набора названий исторических и современных городских объектов: Тарские ворота, Соборная площзадь, Омская крепость, экологический заповедник «Птичья гавань», "Арена-Омск», Парк Победы, Драматический театр, «Зеленый остров», Площуадь Бухгольц̧а др. Средства экспликации субъективного компонента немногочисленны, это лексемы люди, омичи, я, мои родители, моя семья, мои друзья.

Концепт «история» актуализирован в нескольких текстах сочинений с помощью следующего направления развертывания замысла: «указ Петра I - основание города строительство крепости - история Омского драматического театра». Концепт «события» представлен семантической моделью «спортивные события» через развертывание семантики в двух направлениях - «международный Сибирский марафон - памятник марафону - мое участие»; «хоккейные игры “Авангард” - болельщики - мои переживания». Реализация концептов «торговля», «развлечения» в текстах с рекламной направленностью была осуществлена с помощью лексического наполнения инвариантной семантической модели «конкретный локус - вели- чина - выбор - одежда / обувь - развлечения - дети / взрослые - польза - комфорт». Вариации модели незначительны. Актуализация концептов производится одновременно в коммуникативном формате рекламной стратегии «представления уникального предложения» - «объект» - «время, проведенное быстро, экономно, комфортно».

Актуализация концептов «люди», «любовь» связана с представлением других концептов и обусловлена ими.

Общая тенденция репрезентации концептов состоит в актуализации предметных и эмоционально-оценочных компонентов с помощью стратегий «локальная предметизация или привязка к местности», одновременно описания эмоций (реальных или по воспоминаниям), связанных с локусом (Иртышиская набережная - очень уютное и спокойное место для меня; Когда я там (на Соборной площзади) нахожусь, я вспоминаю очень много моментов, связанных с этим местом).

5.3. Сочинения на тему III не отличаются формальной и смысловой сложностью (см. табл. 10).

Для реализации замысла пишущие выбрали либо семантическую модель самопрезентации «Я - индивидуальность», либо противоположную модель «Идеал» / «Мой идеал, кумир».

Базовым в сочинениях этой группы в любой модели семантического развития был 


\section{Способы когнитивного и семантического развертывания текстов сочинений учащихся 7-х классов на тему «На кого я хочу быть похожим», 2016 г.}

\begin{tabular}{|c|c|c|c|}
\hline \multirow[t]{2}{*}{$\begin{array}{c}\text { Негативная модальность } \\
29,4 \%\end{array}$} & \multicolumn{3}{|c|}{$\begin{array}{c}\text { Позитивная модальность } \\
70,6 \% \\
\end{array}$} \\
\hline & $35,2 \%$ & $26,6 \%$ & $8,8 \%$ \\
\hline \multicolumn{4}{|c|}{ Актуализация концептов } \\
\hline $\begin{array}{l}\text { Базовый концепт «Я». } \\
\text { Когнитивные структуры, } \\
\text { реализуюшие концепт: «же- } \\
\text { лание», «стремление», } \\
\text { «мнение», «уникальность», } \\
\text { «личность», «успех» } \\
\text { Кониепты, связанные с ба- } \\
\text { зовым: «мир», «жизнь», } \\
\text { «люди». } \\
\text { Когнитивные структуры } \\
\text { реализующзие концепты, свя- } \\
\text { заннье с базовыл: «опыт», } \\
\text { «ошибки», «любовь», «дея- } \\
\text { тельность», «успешность», } \\
\text { «выдающиеся качества и } \\
\text { достижения» }\end{array}$ & $\begin{array}{l}\text { Базовый концепт «Я». } \\
\text { Когнитивные структуры, } \\
\text { реализуюшчие концепт: } \\
\text { «желание», «стремление», } \\
\text { «мнение», «достижения»/ } \\
\text { «личностные качества» }\end{array}$ & $\begin{array}{l}\text { Базовый концепт «Я». } \\
\text { Когнитивные структуры, } \\
\text { реализуюшие концепт: } \\
\text { «выдающиеся достижения } \\
\text { в мире» }\end{array}$ & $\begin{array}{l}\text { Базовый концепт «Я». } \\
\text { Когнитивные структуры, } \\
\text { реализуюшче концепт: } \\
\text { «успех», «стремление } \\
\text { других брать пример» }\end{array}$ \\
\hline \multicolumn{4}{|c|}{ Базовые семантические модели } \\
\hline $\begin{array}{l}\text { «Отрицание предлагаемого } \\
\text { сценария ↔ утверждение } \\
\text { самобытности ↔ заключе- } \\
\text { ние о полезности чужого } \\
\text { опыта } \leftrightarrow \text { утверждение ин- } \\
\text { дивидуальности и самораз- } \\
\text { вития» }\end{array}$ & $\begin{array}{l}\text { «тверждение предлагае- } \\
\text { мого сценария ↔ выбор } \\
\text { родственников или людей } \\
\text { близкого круга как иде- } \\
\text { ал } \leftrightarrow \text { мотивировка } \leftrightarrow \\
\text { описание их жизни» }\end{array}$ & $\begin{array}{l}\text { «Констатация наличия } \\
\text { идеала, кумира } \leftrightarrow \text { выбор } \\
\text { известной личности как } \\
\text { идеала } \leftrightarrow \text { мотивировка } \leftrightarrow \\
\text { описание ее качеств, дос- } \\
\text { тижений, вклада» }\end{array}$ & $\begin{array}{l}\text { «Констатация необходи- } \\
\text { мости наличия идеала, } \\
\text { кумира ↔ желание дос- } \\
\text { тичь успеха» }\end{array}$ \\
\hline \multicolumn{4}{|c|}{ Отбор слов (тематические группы) } \\
\hline $\begin{array}{l}\text { «Я, «жизнь» (добиться } \\
\text { желаемого в жизни), «лю- } \\
\text { ди» (мои родные, моя сест- } \\
\text { ра, мама, папа, дедушка) } \\
\text { «ситуация» (разные ситуа- } \\
\text { ции, которые были в жизни } \\
\text { мамы, дедушки), «ошибки - } \\
\text { опыт», «индивидуаль- } \\
\text { ность - саморазвитие» (на- } \\
\text { до быть самим собой) }\end{array}$ & $\begin{array}{l}\text { «Я», «семья» (папа, мама, } \\
\text { сестра, дедушка, бабуш- } \\
\text { ка, дядя, тетя, брат), } \\
\text { «ллизкая сфера» (мой } \\
\text { тренер) }\end{array}$ & $\begin{array}{l}\text { «Я», «известные лично- } \\
\text { сти» (Петр I, В. Путин, } \\
\text { Майя Плисецкая, А. Овеч- } \\
\text { кин, Форест Гамп) }\end{array}$ & $\begin{array}{l}\text { «Люди» (мои роднье, моя } \\
\text { сестра, мама, папа, де- } \\
\text { душка), «карьера» (уда- } \\
\text { лось стать хорошим ин- } \\
\text { женером, стал чемпио- } \\
\text { ном по борьбе), «успех» } \\
\text { (добился успеха, победил } \\
\text { серьезного противника, } \\
\text { добился успеха в бизнесе), } \\
\text { «профессионализм» }\end{array}$ \\
\hline
\end{tabular}

концепт «Я», реализованный в высказываниях рефлексивного типа, что задано формулировкой темы. Репрезентация базового концепта и его когнитивных структур в подавляющем большинстве текстов с негативной семантической моделью не имела конкретного воплощения, была осуществлена в рамках общих рассуждений «Нужно быть самим собой», «Хочу построить карьеру», «Большое количество известных людей не пародируют других людей», «Я хочу быть самой собой и быть такой, какая буду».

Среди сочинений с позитивной моделью семантического развития большими по семан- тической, информационной и эмоциональной насыщенности оказались тексты, в которых идеалом выбран близкий человек, что объяснимо личной заинтересованностью пишущих в предмете речи. В качестве образца для подражания в них выступают члены семьи: мамы, папы, сестры, дяди и тети. Концепт «мама» актуализирован в части личностных свойств и качеств: красивая, умная, добрая, спокойная; внешних проявлений по отношению к другим людям: заботливая, ласковая, понимающая, неконфликтная, развеселит, утешит, поддержит в трудную минуту. Концепт «бабушка» репрезентирован неожиданными компонен- 
тами действий и внешних проявлений: uграет на гармошке, поет индийские песни, вкусно готовит, ездит в Индию, сильный характер, никогда не сдается. Концепт «папа» репрезентирован с помощью описания умений: классно водит машину, разбирается в компьютерах; качеств: смекалистый, добрый, весельй, иногда строгий, трудолюбивый; действий в прошлом и настоящем: найдет выход из любой ситуачии, хорошо учился, занимался спортом, ведет здоровый образ жизни, коллекиионирует монетьл.

Доля сочинений, в которых в качестве объекта подражания выступают конкретные известные люди, невелика, так же невелик и своеобразен список личностей. Самыми подробными оказались сочинения о Петре I. Авторами работ являются девочки. Лексемы выдаюшийся, блестящий преобладают в текстах с разными семантическими сценариями, характеризуя отношение говорящих к предмету речи - родственникам, известным людям и пр.

\section{6}

Подведем итоги.

Объем текстов сочинений учащихся 67-х классов соответствует возрастной норме развития языковой способности.

Невысокая либо формальная вариативность лексических, грамматических средств на уровне высказывания и текста, характер распределения указывают на средний уровень их речевой компетенции.

Опыт написания типового текста сформировал у школьников стереотипные когнитивные, коммуникативные, семантические стратегии, работающие на стадии замысла, создания актуального смысла и его воплощения.

В рамках этих стратегий пишущими реализуется ограниченный состав концептов и их компонентов с помощью устойчивых вербальных наборов.

Изменение коммуникативных форматов окружающего школьников дискурсивного пространства привело к формированию в сознании и активному использованию в речи рекламных речевых стратегий (сочинения на тему «Мой город» («Где я люблю бывать в Омске? Почему?»)).
Влияние интернет-дискурсов, приводящее к изменениям в письменной коммуникации (приближению письменной речи к ее разговорной разновидности), ощутимо в проанализированных текстах сочинений на тему «На кого я хочу быть похожим».

Ориентация современного учебного дискурса на актуализацию рефлексии и метарефлексии учащегося сформировала эгоцентрическую направленность текстов сочинений: осознание собственной ценности задало концептуальное и коммуникативное доминирование сферы «Я - личность - несходство с другими» в письменной речи школьников.

\section{ПРИМЕЧАНИЕ}

${ }^{1}$ Работа выполнена при финансовой поддержке гранта РГНФ 15-04-00325а «Детство в дискурсивном пространстве региона: комплексный анализ институциональных и персональных коммуникаций с участием ребенка».

The work was supported by the Russian Foundation for Humanities 15-04-00325a grant. "Childhood in the discursive space of the region: a comprehensive analysis of the institutional and personal communication with the child".

\section{СПИСОК ЛИТЕРАТУРЫ}

1. Бутакова, Л. О. Динамика развития языковой способности и речевой компетенции носителей русского языка. Региональное экспериментальное исследование / Л. О. Бутакова. - Омск : Омск. гос. ун-т им. Ф.М. Достоевского : Вариант-Омск, 2010. $-160 \mathrm{c}$.

2. Бугакова, Л. О. Качества письменной речи сквозь призму отношений «автор - тексп» / Л. О. Бутакова // Русский язык в школе. - 2001. - № 1. - С. 23-29.

3. Бугакова, Л. О. Языковая способность, речевая компетенция в формате не- / естественной письменной речи (на материале сочинений школьников) / Л. О. Бугакова // Вестник Кемеровского государственного университета. - 2016. -№ 3. - С. 101-110.

4. Бугакова, Л. О. Языковая способность, языковая компетенция: способы лингвистической диагностики языкового сознания индивида / Л. О. Бутакова // Языковое бытие человека и этноса: психолингвистический и когнитивный аспекты / под ред. В. А. Пищальниковой. - М. : МГЭИ, 2004. - Вып. 7. C. 25-39.

5. Голев, Н. Д. Письменная коммуникация новейшего времени: основные векторы развития 
/ Н. Д. Голев // Вестник Томского государственного университета. Филология. - № 2 (18). - 2012. C. 5-17.

6. Голев, Н. Д. Речеведение и риторика как основа содержания школьного курса «Русский язык» / Н. Д. Голев // Лингвистика и школа : материалы Всерос. науч.-практ. конф. / под ред. Л. Б. Парубченко. - Барнаул : Изд-во Алт. ун-та, 2001. - С. 95-102.

7. Гольдин, В. Е. Возрастная динамика словесных ассоциаций школьников / В. Е. Гольдин // Язык в движении: к 70-летию Л.П. Крысина. - М. : Языки славянской культуры, 2007. - С. 126-137.

8. Гольдин, В. Е. Личная сфера школьника по данным ассоциативного словаря / В. Е. Гольдин // Вопросы психолингвистики.-2007.-№ 5. - С. 94-99.

9. Гольдин, В. Е. Русский ассоциативный словарь: ассоциативные реакции школьников I-XI классов : в 2 т. / В. Е. Гольдин, А. П. Сдобнова, А. О. Мартьянов. - Саратов : Изд-во Сарат. ун-та, 2011.

10. Гуц, Е. Н. Ассоциативный словарь подростка / Е. Н. Гуц. - Омск : Вариант-Сибирь, 2004. - 156 с.

11. Гуц, Е. Н. Психолингвистическое исследование языкового сознания подростка / Е. Н. Гуц. Омск : Вариант-Сибирь, 2005. - 260 с.

12. Доценко, Т. И. Активные процессы в лексиконе подростка / Т. И. Доценко // Русский язык сегодня: активные языковые процессы конца XX века. М. : Азбуковник, 2003. - Вып. 2. - С. 139-147.

13. Доценко Т. И. Категориальность и ментальный лексикон / Т. И. Доценко // Социо- и психолингвистические исследования. - 2011. - № 15. - С. 74-85.

14. Жинкин, Н. И. Развитие письменной речи учащихся III-VIII классов / Н. И. Жинкин // Язык. Речь. Творчество. Исследования по семиотике, психолингвистике, поэтике. - М. : Лабиринт, 1998. C. $183-319$.

15. Овчинникова, И. Г. Лексикон младшего школьника (характеристика лексического компонента языковой компетенции) / И. Г. Овчинникова, Н. И. Береснева, Л. А. Дубровская, Е. Б. Пенягина. Пермь : Изд-во Перм. ун-та, 2000. - 312 с.

16. Пищальникова, В. А. Интеграция лингвистических дисциплин как объективная необходимость развития современного языковедения / В. А. Пищальникова // Языковое бытие человека и этноса: психолингвистический и когнитивный аспекты. М. ; Барнаул : [б. и.], 2003. - Вып. 6. - С. 3-16.

17. Пищальникова, В. А. Психолингвистика и современное языковедение / В. А. Пищальникова // Методология современной психолингвистики. М. ; Барнаул : Изд-во Алт. ун-та, 2003. - С. 4-22.

18. Рогожникова, Т. М. Опыт исследования становления семантики слова у ребенка / Т. М. Рогожникова // Психолингвистические основы речевого онтогенеза при усвоении родного и иностранного языков : тез. докл. совещ. - М. : [б. и.], 1987. -С. 40-41.
19. Сдобнова, А. П. Лексикон школьника как динамическая система / А. П. Сдобнова. - Саратов : Изд-во Сарат. ун-та, 2015. - 248 с.

20. Яковченко, Е. В. Экспериментальное исследование языковой способности в условиях учебного двуязычия : дис. ... канд. филол. наук / Яковченко Евгения Викторовна. - Барнаул, 2003. - 173 с.

\section{REFERENCES}

1. Butakova L.O. Dinamika razvitiya yazykovoy sposobnosti $i$ rechevoy kompetentsii nositeley russkogo yazyka. Regionalnoe eksperimentalnoe issledovanie [The Dynamics of Development of Language Abilities and Speech Competence of Native Speakers of Russian: Regional Experimental Research]. Omsk, Omsk. gos. un-t im. F.M. Dostoyevskogo Publ.; Variant-Omsk Publ., 2010. 160 p.

2. Butakova L.O. Kachestva pismennoy rechi skvoz prizmu otnosheniy «avtor - tekst» [Quality of Written Speech through the Prism of Relations "Author-Text"]. Russkiy yazyk v shkole, 2001, no. 1, pp. 23-29.

3. Butakova L.O. Yazykovaya sposobnost, rechevaya kompetentsiya $\mathrm{v}$ formate ne- / estestvennoy pismennoy rechi (na materiale sochineniy shkolnikov) [Language Ability, Speech Competence in the Format of non- / natural Written Speech (based on schoolchildren essays)]. Vestnik Kemerovskogo gosudarstvennogo universiteta, 2016, no. 3, pp. 101-110.

4. Butakova L.O. Yazykovaya sposobnost, yazykovaya kompetentsiya: sposoby lingvisticheskoy diagnostiki yazykovogo soznaniya individa [Language Ability, Language Competence: Linguistic Methods of Diagnostics of Linguistic Consciousness of a Person]. Pishchalnikova V.A., ed. Yazykovoye bytiye cheloveka $i$ etnosa: psikholingvisticheskiy $i$ kognitivnyy aspekty. Vyp. 7 [Language and Ethnicity: Psycholinguistic and Cognitive Aspects. Iss. 7]. Moscow, MGEI Publ., 2004, pp. 25-39.

5. Golev N.D. Pismennaya kommunikatsiya noveyshego vremeni: osnovnye vektory razvitiya [Written Communication of Modern Times: Main Vectors of Development]. Vestnik Tomskogo gosudarstvennogouniversiteta. Filologiya, 2012, no. 2 (18), pp. 5-17.

6. Golev N.D. Rechevedenie i ritorika kak osnova soderzhaniya shkolnogo kursa «Russkiy yazyk» [The Study of Speech and Rhetoric as the Basis of the Content of School Course "Russian Language"]. Parubchenko L. B., ed. Lingvistika i shkola: Materialy Vserossiyskoy nauchno-prakticheskoy konferentsii [Linguistics and School: Proceedings of the AllRussian Scientific and Practical Conference]. Barnaul, Izd-vo Alt. un-ta, 2001, pp. 95-102. 
7. Goldin V.E. Vozrastnaya dinamika slovesnykh assotsiatsiy shkolnikov [Age Dynamics of Verbal Language in Schoolchildren Associations]. Yazyk $v$ dvizhenii: $k$ 70-letiyu L.P. Krysina [Language on the Move: to the 70th Anniversary of the L.P. Krysin]. Moscow, Yazyki slavyanskoy kultury Publ., 2007, pp. 126-137.

8. Goldin V. E. Lichnaya sfera shkolnika po dannym assotsiativnogo slovarya [Personal Sphere of the Pupil according to the Associative Dictionary]. Voprosy psikholingvistiki, 2007, no. 5, pp. 94-99.

9. Goldin V. E, Sdobnova A.P., Martyanov A.O. Russkiy assotsiativnyy slovar: assotsiativnye reaktsii shkolnikov I-XI klassov: $v 2 t$. [Russian Associative Dictionary: Associative Reactions of schoolchildren of 1-6 grades. In 2 vols]. Saratov, Izd-vo Saratovskogo un-ta, 2011.

10. Guts E.N. Assotsiativnyy slovar podrostka [Teenager's Associative Dictionary]. Omsk, VariantSibir Publ., 2004. 156 p.

11. Guts E.N. Psikholingvisticheskoe issledovanie yazykovogo soznaniya podrostka [Psycholinguistic Study of Teenager's Linguistic Consciousness]. Omsk, Variant-Sibir Publ., 2005.260 p.

12. Dotsenko T.I. Aktivnye protsessy v leksikone podrostka [Active Processes in Teenager's Vocabulary]. Russkiy yazyk segodnya: aktivnye yazykovye protsessy kontsa XX veka [Russian Language Today: Active Language Processes of the End of the 20th Century]. Moscow, Azbukovnik Publ., 2003, iss. 2, pp. 139-147.

13. Dotsenko T.I. Kategorialnost i mentalnyy leksikon [Categories and Mental Lexicon]. Sotsio- $i$ psikholingvisticheskiye issledovaniya, 2011, no. 15, pp. 74-85.

14. Zhinkin N.I. Razvitie pismennoy rechi uchashchikhsya III-VIII klassov [Development of Written Speech of 3-5 grades Pupils]. Yazyk. Rech. Tvorchestvo. Issledovaniya po semiotike, psikholingvistike, poetike [Language. Speech. Creativity. Research on Semiotics, Psycholinguistics, Poetics]. Moscow, Labirint Publ., 1998, pp. 183-319.
15. Ovchinnikova I.G., Beresneva N.I., Dubrovskaya L.A., Penyagina E.B. Leksikon mladshego shkolnika (kharakteristika leksicheskogo komponenta yazykovoy kompetentsii) [Lexicon of Junior Pupils (Characteristics of Lexical Component of Language Competence)]. Perm, Izd-vo Perm. un-ta, 2000.312 p.

16. Pishchalnikova V.A. Integratsiya lingvisticheskikh distsiplin kak obyektivnaya neobkhodimost razvitiya sovremennogo yazykovedeniya [Integration of Linguistic Disciplines as the Objective Necessity of Modern Linguistics]. Yazykovoe bytie cheloveka i etnosa: psikholingvisticheskiy $i$ kognitivnyy aspekty [Language and Ethnicity: Psycholinguistic and Cognitive Aspects]. Moscow, Barnaul, 2003, Iss. 6, pp. 3-16.

17. Pishchalnikova V.A. Psikholingvistika i sovremennoe yazykovedenie [Psycholinguistics and Modern Linguistics]. Metodologiya sovremennoy psikholingvistiki [Methodology of Modern Psycholinguistics]. Moscow; Barnaul, Izd-vo Alt. unta, 2003, pp. 4-22.

18. Rogozhnikova T.M. Opyt issledovaniya stanovleniya semantiki slova u rebenka [Previous Studies of Child's Word Semantics Formation]. Psikholingvisticheskie osnovy rechevogo ontogeneza pri usvoenii rodnogo i inostrannogo yazykov: tez. dokl. soveshch. [Psycholinguistic Foundations of Speech Ontogenesis in the Assimilation of Native and Foreign Languages: Abstracts of Conference Reports)]. Moscow, 1987, pp. 40-41.

19. Sdobnova A.P. Leksikon shkolnika kak dinamicheskaya sistema [Studen's Lexicon as a Dynamic System]. Saratov, Izd-vo Sarat. un-ta, 2015. $248 \mathrm{p}$.

20. Yakovchenko E.V. Eksperimentalnoe issledovanie yazykovoy sposobnosti $v$ usloviyakh uchebnogo dvuyazychiya: dis. ... kand. filol. nauk [Experimental Study of Language Ability in Conditions of Educational Bilingualism. Cand. philol. sci. diss.]. Barnaul, 2003. $173 \mathrm{p}$.

\section{Information About the Author}

Larisa O. Butakova, Doctor of Sciences (Philology), Professor, Head of Department of Russian, Slavic and Classical Linguistics, Omsk State University named after F.M. Dostoevsky, Prosp. Mira, 55-A, 644043 Omsk, Russian Federation, larisabut@rambler.ru.

\section{Информация об авторе}

Лариса Олеговна Бутакова, доктор филологических наук, профессор, заведующая кафедрой русского языка, славянского и классического языкознания, Омский государственный университет им. Ф.М. Достоевского, просп. Мира, 55-А, 644043 г. Омск, Российская Федерация, larisabut@rambler.ru. 